\title{
Sorption and mobility of thiabendazole in a Brazilian Oxisol
}

\author{
Bianca V. Goulart I; Wallace N. S. Nascimento II; Ana C. Pinto III; \\ Patrícia M. L. L. Fagundes IV; Larissa S. Maciel v; Maria I. N. Alvarenga VI; \\ Márcia M. Kondo VII
}

\begin{abstract}
Thiabendazole is a benzimidazole class drug that is widely used due to its vermifugal and fungicidal properties. The present study investigates the behaviour of TBZ in the A and B horizons of a Red-Yellow Latosol typical of southern Minas Gerais State, Brazil. Adsorption and desorption assays were performed under different $\mathrm{pH}$ conditions (3.0, 4.2-5.1, and 8.5) and a leaching study was conducted using soil columns. The results demonstrated that the behaviour of TBZ in the soil was influenced by the $\mathrm{pH}$, soil organic matter and clay content. The Freundlich constants indicated that the adsorption capacities for horizons $A$ and $B$ were high (50-149 mg1-1/n.L1/n.kg-1) and low (0-24 mg1-1/n.L1/n.kg1 ), respectively. The leaching study results indicated that for both horizons, TBZ presented higher sorption in the initial fractions of the column $(0-2 \mathrm{~cm})$, and that the $B$ horizon had a lower adsorption capacity, compared to the A horizon.
\end{abstract}

Keywords: Adsorption and desorption isotherms; Benzimidazole; Soil

\section{RESUMO}

O tiabendazol é um medicamento da classe benzimidazois amplamente utilizado devido às suas propriedades vermífugas e fungicidas. O presente estudo investiga o comportamento da TBZ nos horizontes A e B de um Latossolo Vermelho-Amarelo típico do sul de Minas

\footnotetext{
I Universidade Federal de Itajubá, Itajubá, Brazil. biancavelosog@gmail.com

II Universidade Federal de Itajubá, Itajubá, Brazil.: wallacenik@hotmail.com

III Universidade Federal de Itajubá, Itajubá, Brazil. anacarollina527@gmail.com

Iv Universidade Federal de Itajubá, Itajubá, Brazil. patriciamaralyne@gmail.com

v Universidade Federal de Itajubá, Itajubá, Brazil. larissasilvamaciel@gmail.com

vI Universidade Federal de Itajubá, Itajubá, Brazil.: minesalvarenga@gmail.com

vII Universidade Federal de Itajubá, Itajubá, Brazil. mmkondo@unifei.edu.br
} 
Gerais, Brasil. Os ensaios de adsorção e dessorção foram realizados sob diferentes condições de pH $(3,0,4,2-5,1$ e 8,5) e o estudo de lixiviação foi realizado utilizando colunas de solo. Os resultados demonstraram que o comportamento da TBZ no solo foi influenciado pelo $\mathrm{pH}$, conteúdo de matéria orgânica e teor de argila do solo. As constantes de Freundlich indicaram que as capacidades de adsorção para os horizontes A e B foram altas (50-149 mg1-1/n.L1/n.kg-1) e baixas (0-24 mg1-1/n.L1/n.kg-1), respectivamente. No estudo de lixiviação o TBZ apresentou maior sorção nas frações iniciais da coluna (0-2 $\mathrm{cm})$, em ambos os horizontes. Além disso, o horizonte $B$ apresentou menor capacidade de adsorção em comparação ao horizonte $A$, indicando maior mobilidade do TBZ neste perfil do solo.

Palavras-chave: Isotermas de adsorção e dessorção; Benzimidazol; Solo.

\section{INTRODUCTION}

Thiabendazole (TBZ) (2-(4-thiazolyl)-1H-benzimidazole) (Figure 1), a member of the benzimidazole class of compounds, was the first anthelmintic to be marketed. Benzimidazoles are extensively used as veterinary drug (VD) due to their broad spectrum of action in animals as well as in humans and are considered emerging contaminants. In addition to use as an antiparasitic, TBZ is also widely employed in agriculture as a fungicide applied to a wide range of fruits and vegetables, before and after harvest (EKMAN et al. 2014; JALALI; DORRAJI, 2014). TBZ acts in the inhibition of specific proteins that compose the parasite microtubules, compromising formation of the cytoskeleton that is crucial for several cellular processes, hence causing the death of the parasite (BÁRTÍKOVÁ et al. 2016; BARRÈRE et al. 2012).

Figure 1 - Molecular structure of TBZ

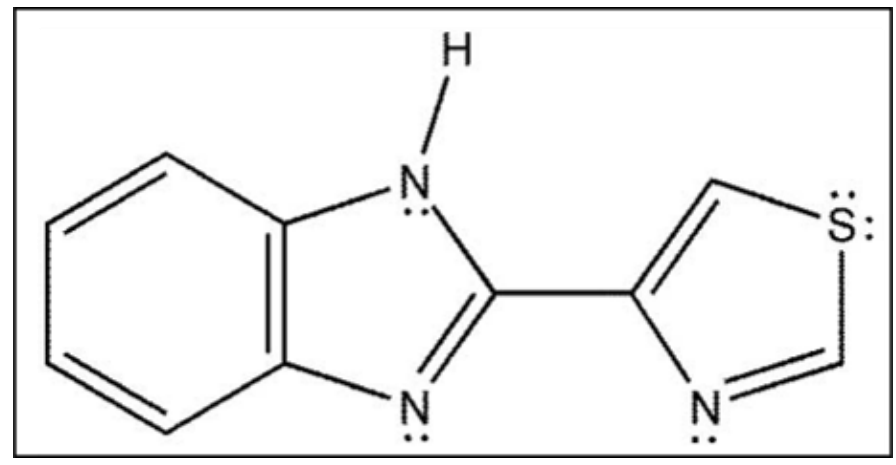


TBZ is a polar organic compound slightly soluble in water. Some of the physicochemical properties of the TBZ are listed in Table 1. Furthermore, due to TBZ ionisation capacity, it can be found in three different forms; cationic, neutral and anionic; according to the $\mathrm{pH}$ value of the medium (EUROPEAN COMMISSION, 2001).

Table 1 - Physicochemical properties of TBZ

\begin{tabular}{ll}
\hline Molecular formula & $\mathrm{C}_{10} \mathrm{H}_{7} \mathrm{~N}_{3} \mathrm{~S}$ \\
\hline Molecular Mass & $201.3 \mathrm{~g} \cdot \mathrm{mol}^{-1}$ \\
Water solubility & $\mathrm{pH} \mathrm{4:} 160 \mathrm{mg} \cdot \mathrm{L}^{-1}$ \\
$\mathbf{( 2 0 ^ { \circ } \mathbf { C } )}$ & $\mathrm{pH} \mathrm{7:} 30 \mathrm{mg} \cdot \mathrm{L}^{-1}$ \\
& $\mathrm{pH} 10: 30 \mathrm{mg} \cdot \mathrm{L}^{-1}$ \\
pKa & pKa1: 2.5 \\
& pKa2: 4.7 \\
log Kow & pKa3: 12.0 \\
Half-life in soil & 2.47 \\
\hline
\end{tabular}

As many VD, after contact with the soil, it can undergo processes such as evaporation, photolysis, and transport in surface runoff. Adsorption can lead to chemical or biological degradation of the VD, uptake by plants, or leaching (OLIVEIRA JR; REGITANO, 2009). The fate of a VD in the soil depends on factors including the physical and chemical properties of the soil, mineralogy, organic matter (OM) content, $\mathrm{pH}$, clay content, temperature, and cation exchange capacity (CEC) (SARMAH et al. 2006). Comprehend the dynamics of VDs in the soil is important for the evaluation of the environmental impact of their use (DIONISIO; RATH, 2016).

Several studies have described the antimicrobial and antiparasitic behaviour of TBZ in the soil (RATH et al., 2016; DORETTO et al. 2014; DIONISIO; RATH, 2016; VIEIRA et al. 2017). The sorption of TBZ has been investigated using four different soils commonly found in São Paulo State (OLIVEIRA NETO et al. 2017). However, there have been no studies reported in the literature using soils from the southern region of Minas Gerais State. Therefore, the aim of the present study was to determine the adsorption and desorption coefficients and leaching capacity of TBZ in the A and B horizons of a RedYellow Latosol (Oxisol) from State of Minas Gerais, Brazil. 


\section{EXPERIMENTAL}

\subsection{Chemicals}

Thiabendazole (CAS 148-79-8, 99.23\%) was obtained from Dermadia Manipulação (Pouso Alegre, Minas Gerais, Brazil). Calcium chloride (99.0-105.0\%) was from Synth (Diadema, São Paulo, Brazil). All solutions were prepared using ultrapure water obtained from a Milli-Q system (Millipore).

\subsection{Soil samples}

The soil samples were collected in Itajubá, Minas Gerais State, Brazil (22²4'48.6"S, $\left.45^{\circ} 26^{\prime} 15.8^{\prime \prime} \mathrm{W}\right)$, from horizons $A(50 \mathrm{~cm}$ depth) and B (75 cm depth). The soils were airdried for 7 days, sieved (particle size $\leq 2 \mathrm{~mm}$ ), and stored at room temperature. The physical and chemical characteristics of the soils were determined following procedures established by Empresa Brasileira de Pesquisa Agropecuária (EMBRAPA, 1997).

\section{ANALYTICAL METHOD}

Determination of the concentration of TBZ in aqueous solution was carried out by molecular absorption spectrometry, using a Varian Cary 50 instrument operated at $\lambda=$ $299 \mathrm{~nm}$ (Oliveira Neto et al. 2017). The analytical method was validated by determining the selectivity, linearity, accuracy, robustness, limit of detection (LOD), and limit of quantification (LOQ) (RIBANI et al. 2004; ANVISA, 2003).

\section{ADSORPTION STUDIES}

The procedures used for investigation of the adsorption and desorption of TBZ by the soil samples followed OECD guideline 106 (OECD, 2000). The tests were performed in $50 \mathrm{~mL}$ polypropylene Falcon tubes, using 0.5 and $1.0 \mathrm{~g}$ of soils from horizons $A$ and $B$, respectively, and $25 \mathrm{~mL}$ of a solution of TBZ at different concentrations (6.0, 9.0, 12.0,

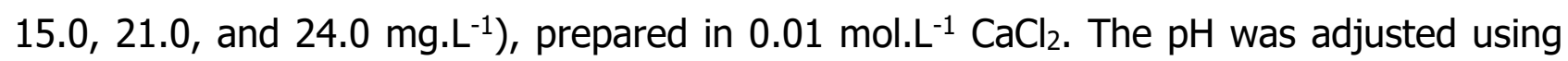
solutions of $\mathrm{NaOH}$ or $\mathrm{HCl}$ and the suspensions were maintained under agitation at 120 rpm, in the dark. Control solutions were prepared without the addition of soil. After 24 h, the suspensions were centrifuged, filtered through $0.45 \mu \mathrm{m}$ pore size membranes 
(Química Moderna), and the TBZ concentrations were determined. All the experiments were performed in triplicate.

For the desorption study, $25 \mathrm{~mL}$ of $0.01 \mathrm{~mol}^{-1} \mathrm{CaCl}_{2}$ solution were added to the Falcon tubes containing the solid residues remaining from the adsorption study. The $\mathrm{pH}$ values were adjusted and the suspensions were maintained under agitation at $120 \mathrm{rpm}$ for $48 \mathrm{~h}$ (twice the adsorption period), followed by centrifugation, filtration, and quantification of the desorbed TBZ (EMBRAPA, 1997; OECD, 2000).

\section{LEACHING EXPERIMENTS}

PVC tubes (30 cm height, $9.5 \mathrm{~cm}$ internal diameter) were used for the soil columns. Plastic grids ( $2.0 \mathrm{~mm}$ mesh size) were placed at the bases of the tubes, followed by addition of the soil samples, leaving a $5 \mathrm{~cm}$ space between the surface of the soil column and the top of the PVC tube. A $0.1 \mathrm{~g}$ mass of TBZ was placed on the top of the soil column and rain water was then added at rates that were in accordance with the precipitation volume reported for Itajubá by Mello et al. (2007) for the months of the study (August and September of 2015). At the end of each period of rain simulation (after $7,14,21$, and 28 days), three columns of each soil horizon were left at room temperature until complete dryness, followed by division of the soil columns into $2.0 \mathrm{~cm}$ sections. The soil portions were sieved to a particle size smaller than $2 \mathrm{~mm}$ and masses of $0.5 \mathrm{~g}$ were used to study the desorption of TBZ, as described above.

\section{RESULTS AND DISCUSSION}

\subsection{TBZ determination by UV spectrophotometry}

The satisfactory linearity of the spectrophotometric method was confirmed by a linear regression coefficient $\left(R^{2}\right)$ of 0.9999 . The limits of detection and quantification were 0.17 and $0.58 \mathrm{mg}^{-1}{ }^{-1}$, respectively. The accuracy of the method was determined by the recovery technique, resulting in a value of $100 \%$.

\subsection{Soil characterization}

The soils from the A and B horizons consisted mainly of clay and presented acidic $\mathrm{pH}$ in $0.01 \mathrm{~mol} \mathrm{~L}^{-1} \mathrm{CaCl}_{2}$ solution (Table 2). Due to its higher contents of organic matter 
and clay, the A horizon showed a higher cation exchange capacity (CEC), compared to the $B$ horizon. The cation exchange capacity is highly correlated with the presence of organic carbon and clay minerals, as reported by Soares and Alleoni (2008) who found that $95 \%$ of the CEC in Oxisols was due to the contribution of the organic carbon content.

Table 2 - Physical and chemical characteristics of the soils

\begin{tabular}{lcc}
\hline Property & A Horizon & B Horizon \\
\hline $\mathrm{pH}\left(\right.$ in $\left.0.01 \mathrm{~mol} \mathrm{~L}^{-1} \mathrm{CaCl}_{2}\right)$ & 4.2 & 5.1 \\
Organic matter $(\mathrm{OM})(\% \mathrm{w} / \mathrm{w})$ & 1.72 & 0.17 \\
Cation exchange capacity (CEC) $\left(\mathrm{cmolc} \mathrm{dm}^{-3}\right)$ & 2.37 & 0.28 \\
Texture (\%) & & \\
Sand & $32.8 \pm 0.12$ & $33.9 \pm 0.87$ \\
Silt & $13.4 \pm 2.4$ & $28.1 \pm 1.67$ \\
Clay & $53.8 \pm 2.52$ & $38.0 \pm 1.34$ \\
\hline
\end{tabular}

\subsection{Adsorption studies}

Tests of different soil/solution ratios for use in the adsorption study showed that the best results were obtained using ratios of $1 / 50(w / v)$ and $1 / 25(w / v)$ for the soils from horizons $A$ and $B$, respectively. These ratios resulted in adsorption percentages higher than $50 \%$, as recommended by OECD (2000). In addition, the TBZ concentrations obtained after the adsorption/desorption processes were higher than the LOQ.

\subsection{Sorption/desorption isotherms}

The experimental adsorption and desorption data for the soils from horizons $A$ and $B$ were fitted using the Freundlich and Langmuir isotherm models. The comparison between both isotherm models, using the $\mathrm{A}$ horizon without $\mathrm{pH}$ adjustment, showed that the linear correlation coefficients for the Langmuir model ( $R^{2}$ ads 0.9850 and $R^{2}$ des 0.8565 ) (Figure 2) were not as good as for those obtained for the Freundlich isotherm ( $R^{2}$ ads 0.9953 and $R^{2}$ des 0.9560 ) (Figure 3). 
Figure 2 - Linearized Langmuir isotherms for the adsorption and desorption of TBZ in the A horizon of the Red-Yellow Latosol without pH adjustment

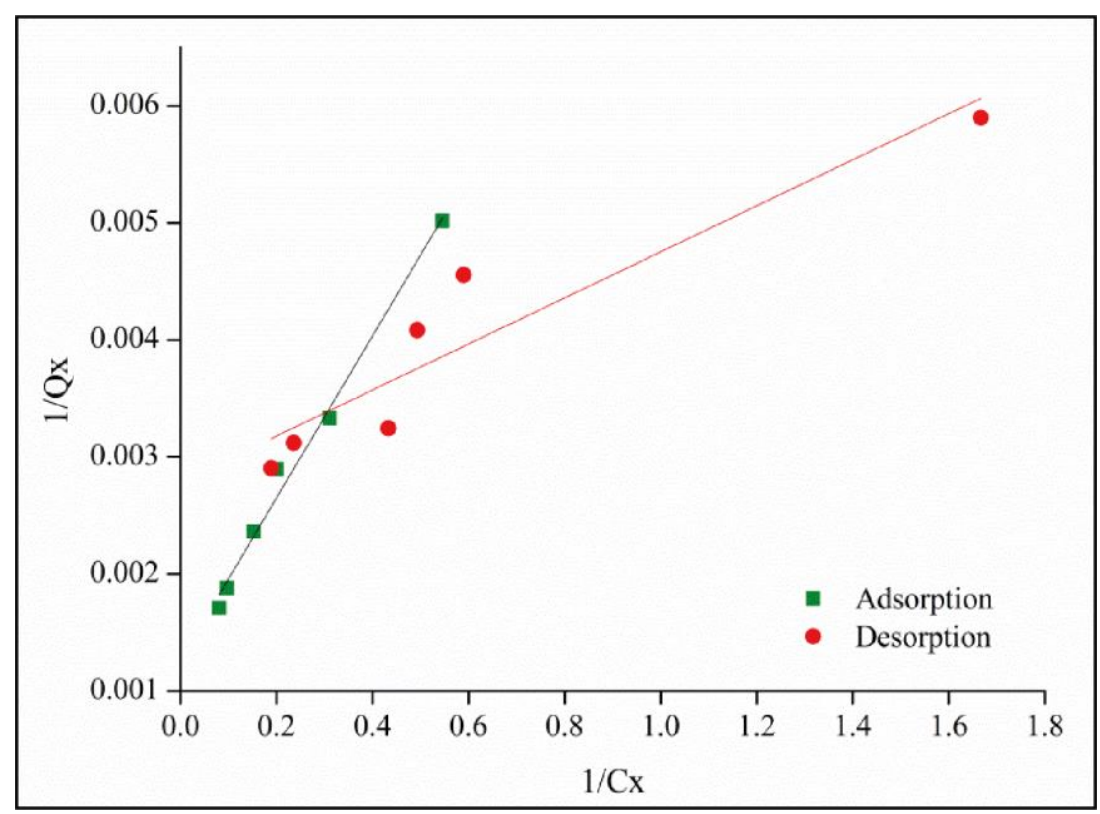

Therefore, the data presented were adjusted using just the Freundlich model (Figures 3 and 4, respectively). Table 3 provides the Freundlich coefficient $\left(K_{F}\right), 1 / n$, and $\mathrm{R}^{2}$ values obtained for the soil.

Figure 3 - Linearized Freundlich isotherms for the adsorption (a) and desorption (b) of TBZ in the A horizon of the Red-Yellow Latosol, under different pH conditions

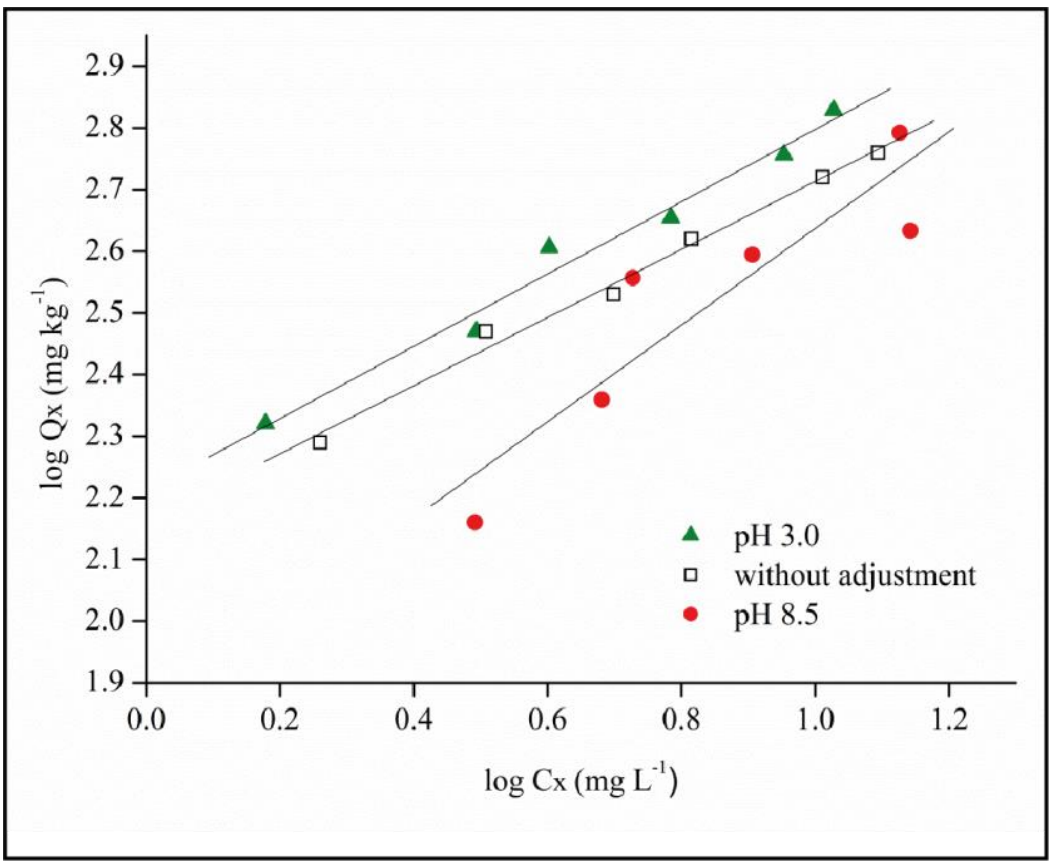

(a) 


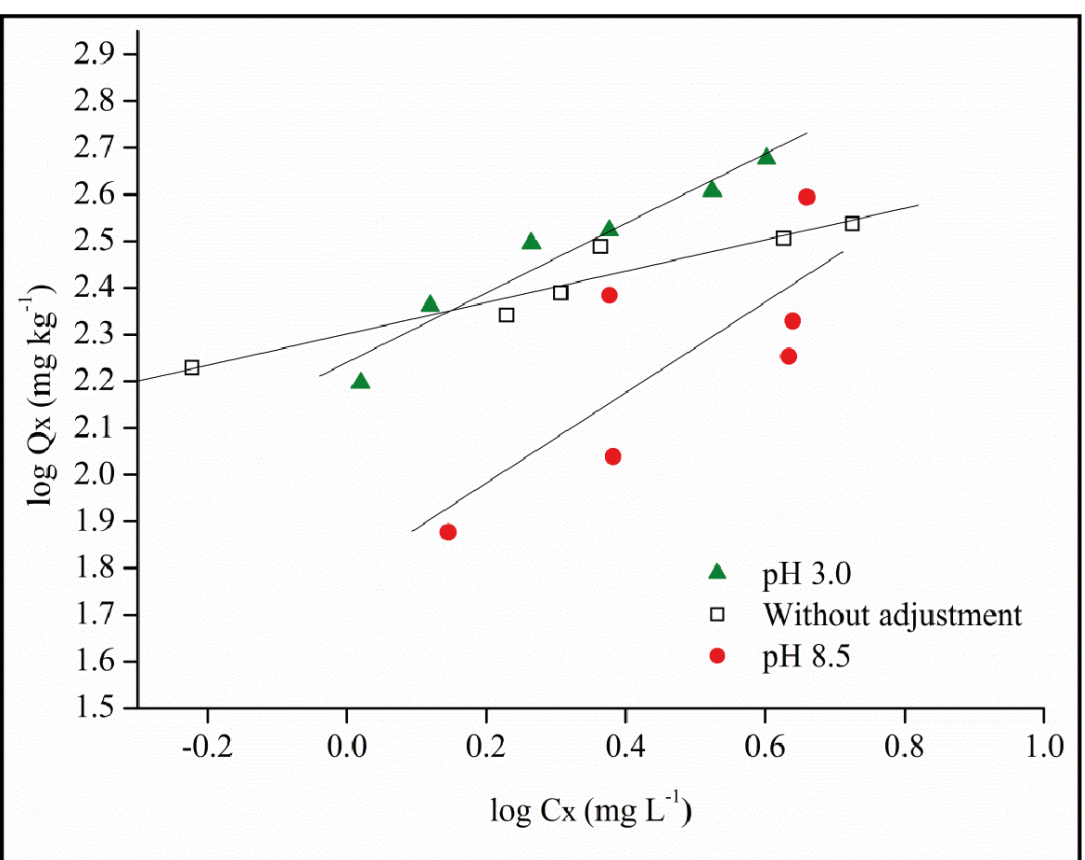

(b)

Figure 4 - Linearized Freundlich isotherms for the adsorption under different $\mathrm{pH}$ conditions (a) and desorption at $\mathrm{pH} 3.0$ (b) of TBZ in the B horizon of the Red-Yellow Latosol

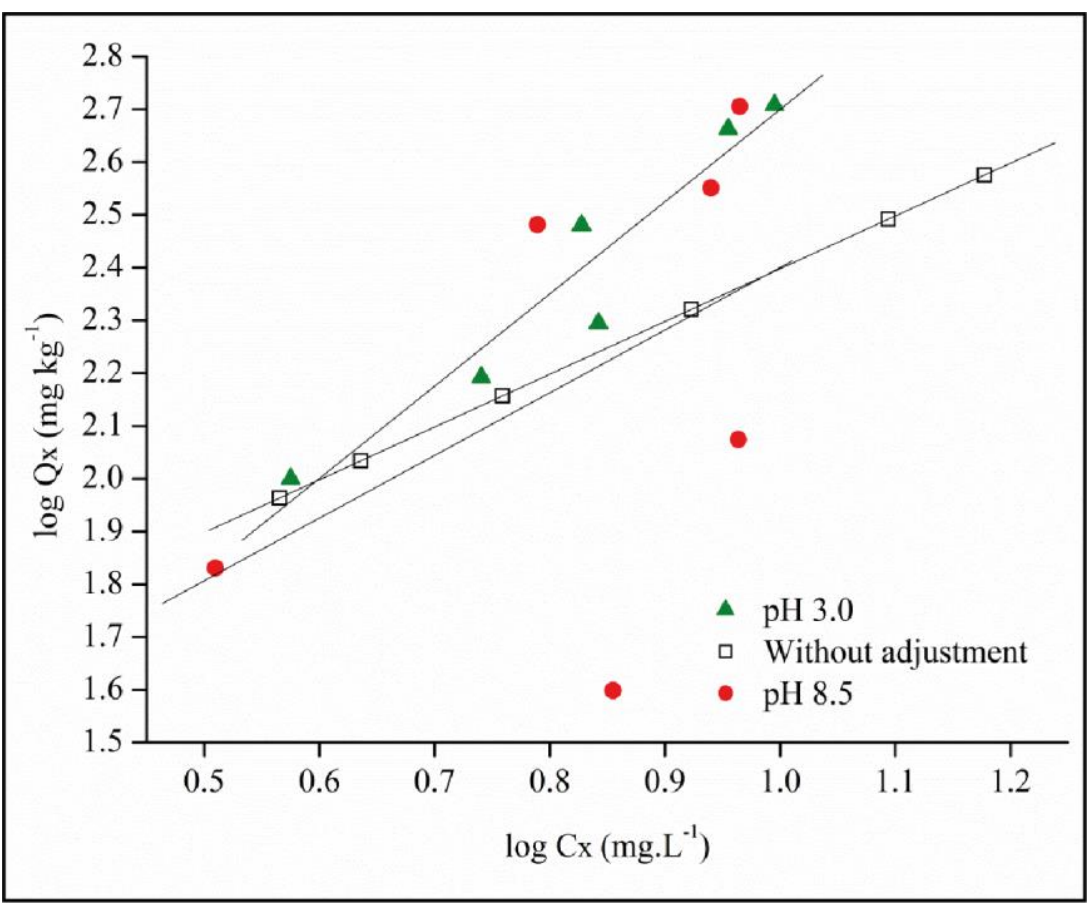

(a) 


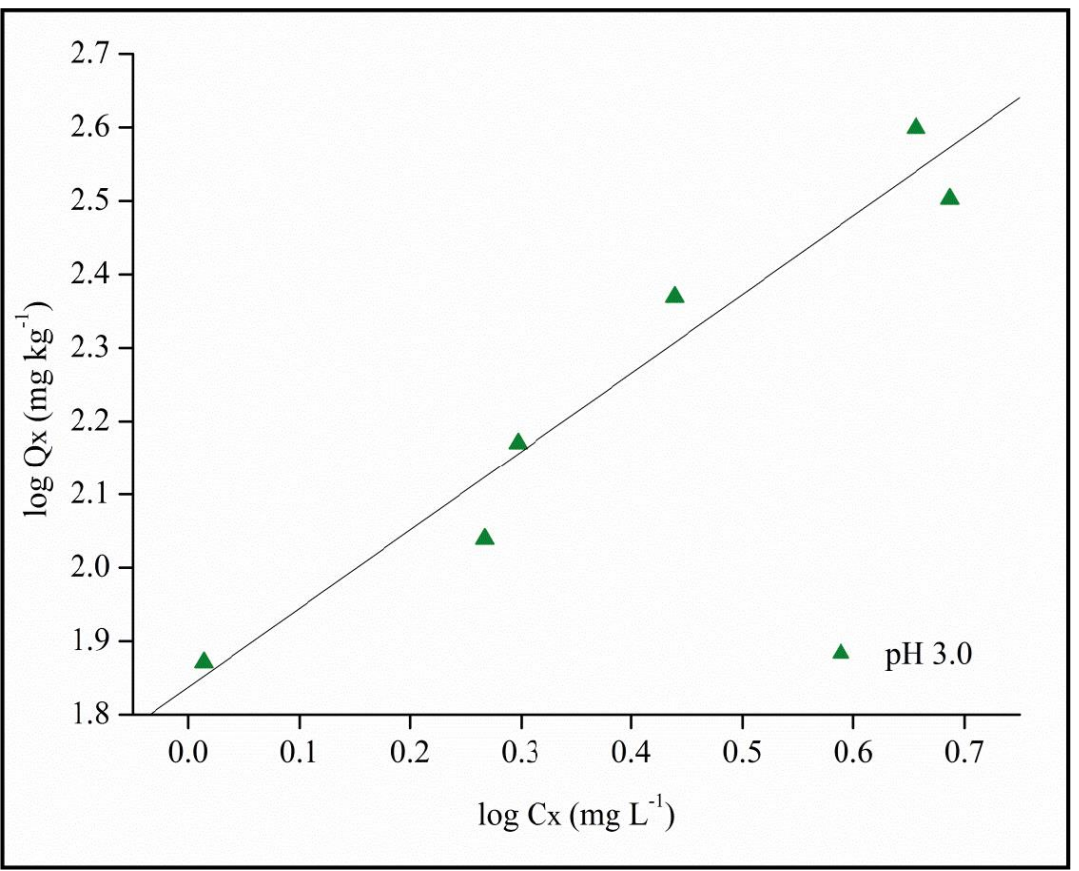

(b)

Table 3 - Comparison of adsorption indexes $\left(\mathrm{K}_{\mathrm{F}}, \mathrm{mg}^{1-1 / \mathrm{n}} \mathrm{L}^{1 / \mathrm{n}} \mathrm{kg}^{-1}\right)$, Freundlich exponents $(1 / n)$, and linearized correlation coefficients $\left(R^{2}\right)$ for horizons $A$ and $B$ of the Red-Yellow Latosol

\begin{tabular}{|c|c|c|c|c|c|c|}
\hline \multicolumn{7}{|l|}{ A Horizon } \\
\hline \multirow{2}{*}{ pH conditions } & \multicolumn{2}{|l|}{$\mathrm{K}_{\mathrm{F}}$} & \multicolumn{2}{|l|}{$1 / n$} & \multicolumn{2}{|l|}{$\mathrm{R}^{2}$} \\
\hline & Ads & Des & Ads & Des & Ads & Des \\
\hline 3.0 & 162.7 & 173.94 & 0.5863 & 0.7445 & 0.9903 & 0.9715 \\
\hline $4.0-4.5$ & 144.9 & 200.2 & 0.5523 & 0.336 & 0.9953 & 0.9560 \\
\hline $8.0-8.5$ & 71.33 & 61.5 & 0.7838 & 0.9676 & 0.9118 & 0.7826 \\
\hline \multicolumn{7}{|l|}{ B Horizon } \\
\hline \multirow{2}{*}{ pH conditions } & $\mathrm{K}_{\mathrm{F}}$ & & $1 / n$ & & $\mathrm{R}^{2}$ & \\
\hline & Ads & Des & Ads & Des & Ads & Des \\
\hline 3.0 & 8.93 & 668.70 & 1.749 & 1.071 & 0.9599 & 0.9745 \\
\hline $4.0-4.5$ & 24.99 & - & 1.0002 & - & 1.0 & - \\
\hline $8.0-8.5$ & 16.33 & - & 1.1875 & - & 0.4710 & - \\
\hline
\end{tabular}

According to the classification of adsoprtion capacity from the Instituto Brasileiro do Meio Ambiente e dos Recursos Naturais Renováveis (IBAMA), and based on Freundlich constants $\left(\mathrm{K}_{\mathrm{F}}\right)$ determined in different $\mathrm{pH}$ conditions, the adsorption of TBZ in $\mathrm{A}$ and $\mathrm{B}$ horizon was considered high (between $50-149 \mathrm{mg}^{1-1 / \mathrm{n}} \mathrm{L}^{1 / \mathrm{n}} \mathrm{kg}^{-1}$ ) and low (between 0 - 24 $\left.\mathrm{mg}^{1-1 / n} \mathrm{~L}^{1 / n} \mathrm{~kg}^{-1}\right)$, respectively. The high adsorption of TBZ in the $A$ horizon soil could be 
explained by the ionisation capacity of TBZ under different $\mathrm{pH}$ conditions and due to the higher MOS and clay mineral in the A horizon. According to Oliveira Jr and Regitano (2009) the adsorption of molecules with basic character is due to electrostatic interactions with components of the organic matter, since the composition of SOM includes humic substances that can present negative charge balance under certain $\mathrm{pH}$ conditions. In addition to these interactions, other possible mechanisms of adsorption are cationic exchange and hydrogen interactions between the benzimidazole and the humic SOM components and clay minerals.

The sorption studies with the A horizon soil indicated a greater adsorption capacity at $\mathrm{pH} 3.0\left(\mathrm{~K}_{\mathrm{F} \text { Ads }}=162.7 \mathrm{mg} \mathrm{g}^{1-1 / \mathrm{n}} \cdot \mathrm{L}^{1 / \mathrm{n}} \cdot \mathrm{kg}^{-1} ; \mathrm{K}_{\mathrm{F} \text { Des }}=173.94 \mathrm{mg} \mathrm{g}^{1-1 / \mathrm{n}} \cdot \mathrm{L}^{1 / \mathrm{n}} \cdot \mathrm{kg}^{-1}\right)$. This could be attributed to the higher contribution of the cationic form of TBZ at this $\mathrm{pH}(93 \%)$, resulting in electrostatic interactions between TBZ and the SOM and clay mineral components of the soil. ${ }^{25}$ At the other $\mathrm{pH}$ values studied, there were also contributions from hydrogen bonding and Van der Waals interactions. A lower adsorption capacity was observed under basic conditions $(\mathrm{pH} 8.0-8.5)\left(\mathrm{K}_{\mathrm{F}}\right.$ Ads $=71.33 \mathrm{mg}^{1-1 / \mathrm{n}} \cdot \mathrm{L}^{1 / \mathrm{n}} \cdot \mathrm{kg}^{-1} ; \mathrm{K}_{\mathrm{F} \text { Des }}=61.5$ $\left.\mathrm{mg}^{1-1 / \mathrm{n}} \cdot \mathrm{L}^{1 / \mathrm{n}} \cdot \mathrm{kg}^{-1}\right)$, when the neutral form of TBZ is predominant (99\%). In this case, a possible mechanism of adsorption was the existence of hydrophobic interactions between TBZ and SOM, since the TBZ molecule contains lipophilic groups in its structure (benzyl ring) and is only slightly soluble at basic pH (OLIVEIRA NETO et al. 2017).

The $\mathrm{B}$ horizon soil showed low adsorption capacities under different $\mathrm{pH}$ conditions, which could be attributed to low contents of the organic matter and clay minerals that are important in the sorption process (SOARES; ALLEONI, 2008). For this horizon, the highest adsorption was observed at $\mathrm{pH}$ 4.0-4.5 $\left(\mathrm{K}_{\mathrm{F}}\right.$ Ads $\left.=24.99 \mathrm{mg}^{1-1 / \mathrm{n}} \cdot \mathrm{L}^{1 / \mathrm{n}} \cdot \mathrm{kg}^{-1}\right)$, at which TBZ can be found in both the cationic (63\%) and neutral (37\%) forms.

TBZ is a polar ionisable organic compound ( $\left.\mathrm{pKa}_{1}: 2.5 ; \mathrm{pKa}_{2}: 4.7 ; \mathrm{pKa}_{3}: 12.0\right)$ that is slightly soluble in water (160 mg. $\mathrm{L}^{-1}$ at $\mathrm{pH} 4.0 ; 30 \mathrm{mg} \cdot \mathrm{L}^{-1}$ at $\mathrm{pH} \geq 7.0$ ) [26]. Furthermore, the ionisation capacity of TBZ means that it can be found in different ionic forms, depending on the $\mathrm{pH}$ (EUROPE COMMISSION, 2001).

Oliveira Neto et al. (2017) studied the TBZ adsorption in different soils from São Paulo State and observed a low to moderate adsorption, depending on the $\mathrm{pH}$ conditions. Higher adsorption and desorption capacities $\left(\mathrm{K}_{\mathrm{F}}\right.$ Ads $=58 \mathrm{mg}^{1-1 / \mathrm{n}} \cdot \mathrm{L}^{1 / \mathrm{n}} \cdot \mathrm{kg}^{-1} ; \mathrm{K}_{\mathrm{F}}$ Des $=73 \mathrm{mg}^{1-}$ $\left.{ }^{1 / n} . \mathrm{L}^{1 / \mathrm{n}} . \mathrm{kg}^{-1}\right)$ were observed for soil with higher contents of clay (54.6\%) and OM (2.88\%), under acidic conditions ( $\mathrm{pH}$ 3.8-4.2). Soil with a greater sand component and lower organic matter content showed lower adsorption and desorption capacities for TBZ ( $\mathrm{K}_{\mathrm{F}}$ Ads 
$=9 \mathrm{mg}^{1-1 / \mathrm{n}} \cdot \mathrm{L}^{1 / \mathrm{n}} \cdot \mathrm{kg}^{-1} ; \mathrm{K}_{\mathrm{F}}$ Des $\left.=10 \mathrm{mg}^{1-1 / \mathrm{n}} \cdot \mathrm{L}^{1 / \mathrm{n}} \cdot \mathrm{kg}^{-1}\right)$, at $\mathrm{pH}$ 5.5-5.7. El-Nahhal (2014) also studied the influence of $\mathrm{pH}$ on the TBZ adsorption process in clay minerals (bentonite clay) and showed that an acidic $\mathrm{pH}(\mathrm{pH} 3.0)$ was more favourable for adsorption, compared to conditions with higher $\mathrm{pH}$ (pH 5.5-9.0). Zahra et al. (2017) determined Linear and Freundlich coefficients and kinetics of TBZ in different agricultural soils of Pakistan. The authors observed that the values of adsorption coefficients increased with the increase of SOM, CEC and clay content of the soils. The influence of soil pH on the sorption process was also evaluated and results were that soils with lower values of $\mathrm{pH}$ showed higher values of adsorption coefficients and lower values desorption coefficients.

In the present study, the non-equivalence of the adsorption and desorption isotherms in horizon A indicated that TBZ sorption onto the soil is a reversible process and that part of the adsorbed TBZ can be released into the soil solution. The desorption isotherms showed that TBZ was partially desorbed from the A horizon soil, with recovery in the range of $15 \%$ and $25 \%$. Therefore, these results showed a partial mobility of TBZ in this soil, indicating that the compound could undergo processes such as biodegradation or transport to aquatic environments.

The studies performed with the B horizon soil indicated that the TBZ sorption process was only reversible at $\mathrm{pH} 3.0$, with $32 \%$ desorption for the sample that presented the highest adsorption. In the experiments carried out at pH 4.0-4.5 and pH 8.0-8.5, it was not possible to determine the percentage desorption, because the final concentrations were below the LOQ of the analytical method. This could have been due to irreversible binding of TBZ to the sorption sites, or to difficulty in attaining stable equilibrium conditions.

\subsection{Leaching experiments}

The results of the leaching experiments indicated that for the soils from both horizons, there was higher sorption of TBZ in the initial fractions of the column $(0-2 \mathrm{~cm})$. For the A horizon soil, TBZ was quantified in the soil solutions obtained for all the column sections (0-18 cm), with the concentration decreasing according to depth (Figure 4). In the case of the B horizon soil, TBZ could only be quantified in the first $10 \mathrm{~cm}$ of the soil column, because the TBZ concentrations in the soil fractions lower than $10 \mathrm{~cm}$ were below the LOQ of the analytical method (Figure 5). 
Figure 4 - Leaching of TBZ in the A horizon of the Red-Yellow Latosol during a 21-day period

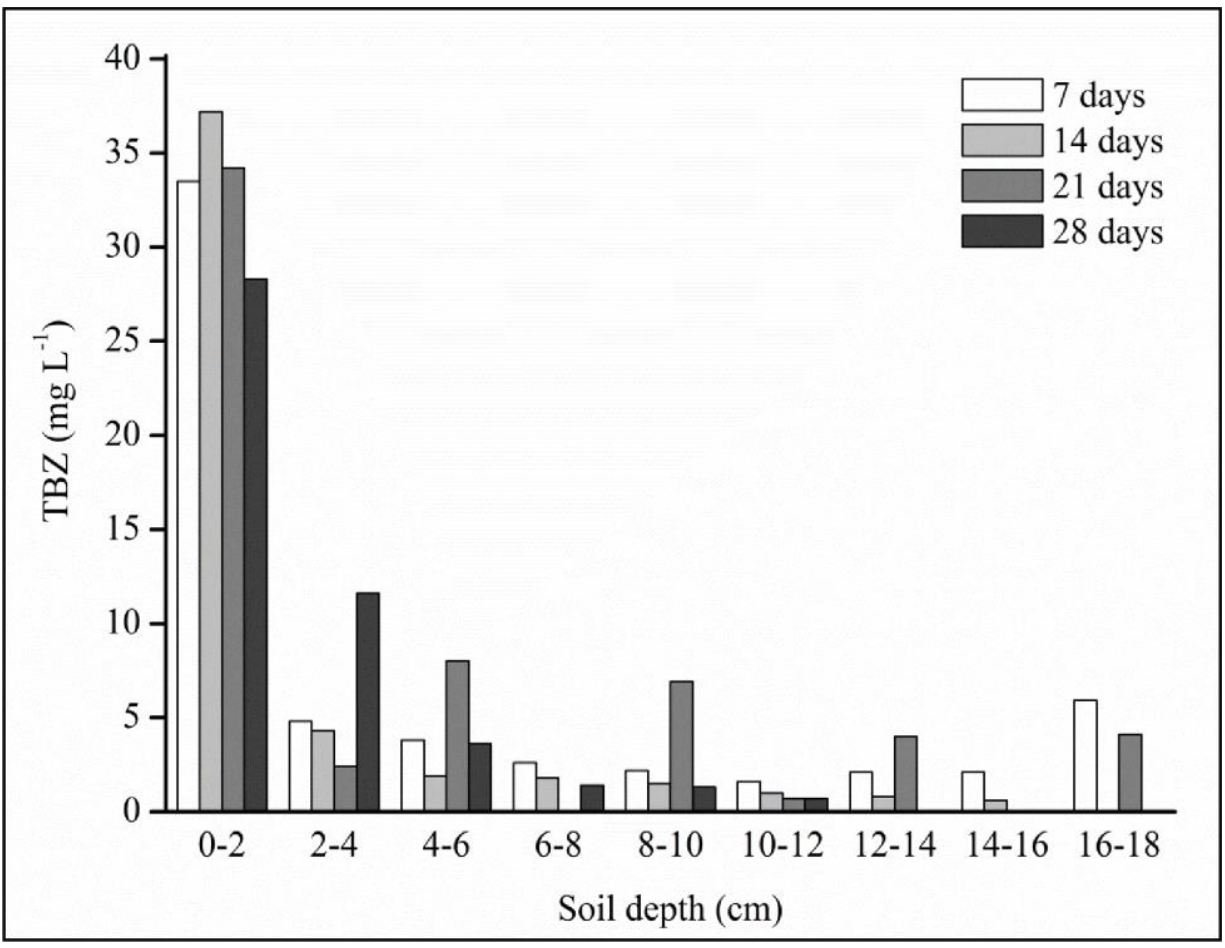

Figure 5 - Leaching of TBZ in the B horizon of the Red-Yellow Latosol during a 21-day period

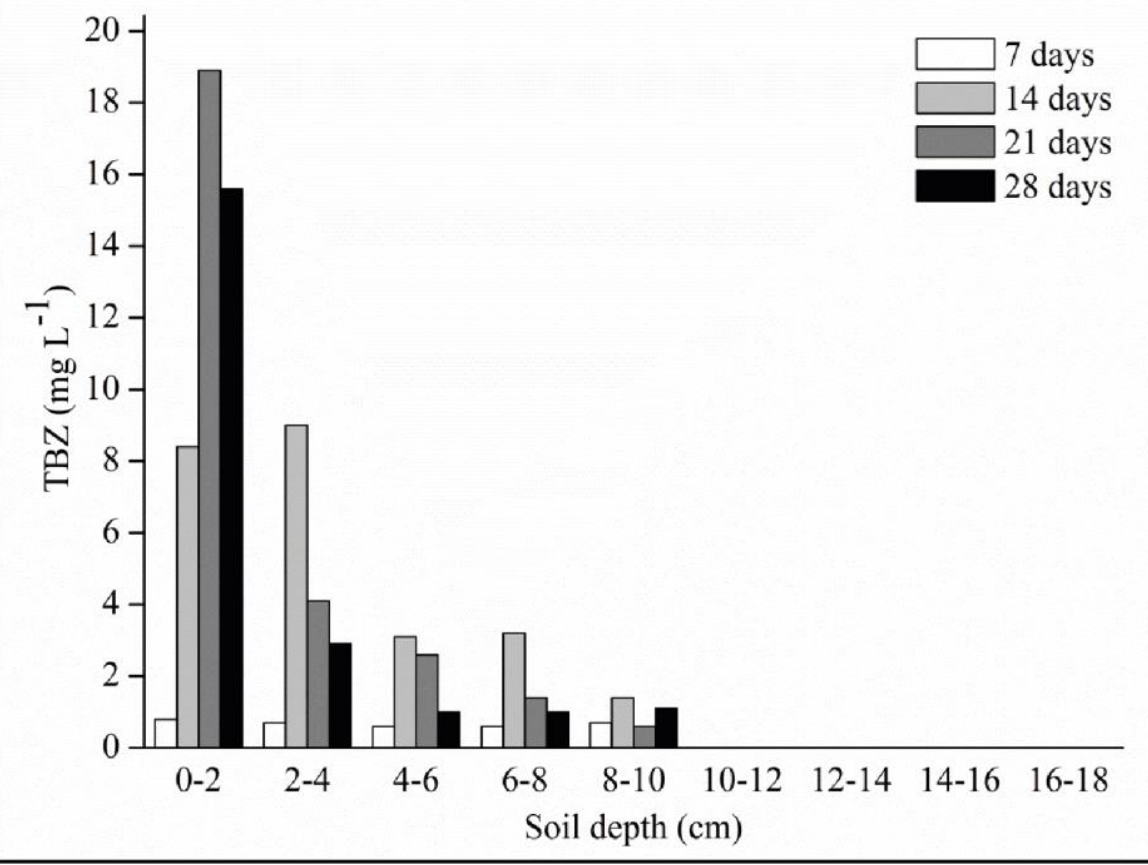


The lower adsorption capacity of the $B$ horizon soil could be explained by the lower contents of organic matter and clay, compared to the A horizon, which resulted in weaker interactions between TBZ and the soil components.

\section{CONCLUSIONS}

The results indicated that the adsorption of TBZ in the soil was influenced by the $\mathrm{pH}$, because the TBZ molecule can exist in different ionisable forms. The sorption/desorption process was fitted using the Freundlich model, and it was observed that at more acidic $\mathrm{pH}$, adsorption of the compound on the soil surface was due to electrostatic interactions between the cationic form of TBZ and the SOM and clay soil components. The sorption processes in the soils from the two horizons were dissimilar, because the contents of organic matter and clay minerals were different.

In the leaching study, greater adsorption of TBZ was observed in the upper portions of the columns, for both horizons studied. Due to the lower sorption capacity of the B horizon soil, TBZ was only slightly adsorbed in the $10-18 \mathrm{~cm}$ soil fractions and could not be quantified in the soil solutions obtained after the desorption process.

\section{ACKNOWLEDGMENTS}

The authors would like to thank Coordenação de Aperfeiçoamento de Pessoal do Nível Superior (CAPES) for a fellowship. Financial support was provided by Rede Mineira de Química (RQ-MG) and Fundação de Amparo à Pesquisa do Estado de Minas Gerais (FAPEMIG).

\section{REFERENCES}

BARRÈRE V, ALVAREZ L, SUAREZ G, CEBALLOS L, MORENO L, LANUSSE $C$ et al. Relationship between increased albendazole systemic exposure and changes in single nucleotide polymorphisms on the $\beta$-tubulin isotype 1 encoding gene in Haemonchus contortus. Vet. Parasitol. 2012; 186(3-4):344- 349.

BÁRTÍKOVÁ H, PODLIPNÁ R, SKÁLOVÁ L. Veterinary drugs in the environment and their toxicity to plants. Chemosphere. 2016; 144:2290-2301. 
BRASIL. MINISTÉRIO DA SAÚDE. Agência Nacional de Vigilância Sanitária (ANVISA). Resolução RE no 899, de 29 de maio de 2003. Determina a publicação do "Guia para validação de métodos analíticos e bioanalíticos"; fica revogada a Resolução RE no 475, de 19 de março de 2002 Brasília. Diário Oficial da União, Poder Executivo, Brasília (Brasil); 2003.

BUNDSCHUH M, HAHN T, EHRLICH B, HÖLTGE S, KREUZING R, SCHULZ R. Acute Toxicity and Environmental Risks of Five Veterinary Pharmaceuticals for Aquatic Macroinvertebrates. Bull Environ Contam Toxicol. 2016:96:139-143.

DIONISIO AC, RATH S. Abamectin in soils: Analytical methods, kinetics, sorption and dissipation. Chemosphere. 2016; 151:17-29.

DORETTO KM, PERUCHI LM, RATH S. Sorption and desorption of sulfadimethoxine, sulfaquinoxaline and sulfamethazine antimicrobials in Brazilian soils. Sci Total Environ. 2014; 476-477, 406-414.

EKMAN E, FANIBAND MH, LITTORIN M, MAXE M, JÖNSSON BA, LINDH CH. Determination of 5-hydroxythiabendazole in human urine as a biomarker of exposure to thiabendazole using LC/MS/MS. J. Chromatogr. B. 2014; 973C:61-67.

EL-NAHHAL YZ. Development of controlled release formulations of thiabendazole. J. Agric Chem Environ. 2014;3(1):1-8.

EMBRAPA. Manual de métodos de análise de solo. Centro Nacional de Pesquisa de Solos. 2. ed.. Rio de Janeiro: Rev. Atual; 1997.

EUROPEAN COMMISSION. Review report for the active substance thiabendazole finalised in the Standing Committee on Plant Health at its meeting on 12 December 2000 in view of the inclusion of thiabendazole in Annex I of Directive 91/414/EEC. 7603/VI/97- final, p 41; 2001.

FRADE F, DIAS M, TEIXEIRA ACSC, PALMA MAS. Environmental contamination by fluoroquinolones. Braz J Pharm Sci. 2014; 50(1):41-54.

HÖRSING M, LEDIN A, GRABIC R, FICK J , TYSKLIND M, JANSEN JLAC et al. Determination of sorption of seventy-five pharmaceuticals in sewage sludge. Water Res. 2011; 45(15):4470-4482.

INSTITUTO BRASILEIRO DE GEOGRAFIA E ESTATÍSTICA (IBGE) [Internet]. Censo 2017. Available from: https://www.ibge.gov.br/estatisticas-novoportal/economicas/agricultura-epecuaria/21814-2017-censo-agropecuario.html.

INSTITUTO BRASILEIRO DE GEOGRAFIA E ESTATÍSTICA (IBGE) [Internet]. Produção da Pecuária Municipal2017. Available from: https://biblioteca.ibge.gov.br/visualizacao/periodicos/84/ppm_2017_v45_br_informativo.p df.

JALALI $F$, DORRAJI PS. Interaction of anthelmintic drug (thiabendazole) with DNA: Spectroscopic and molecular modeling studies. Arab J of Chem. 2014;10(Suppl 2): S3947S3954. 
JALIL MER, RODRIGO SV, AZEVEDO D, BASCHINI M, SAPAG K. Improvement in the adsorption of thiabendazole by using aluminum pillared clays. Appl Clay Sci. 2013; 71:55-63.

MAXIMIANO AA, FERNANDES RO, NUNES FP, ASSIS MP, MATOS RV, BARBOSA CGS et al. Utilização de drogas veterinárias, agrotóxicos e afins em ambientes hídricos: demandas, regulamentação e considerações sobre riscos à saúde humana e ambiental. Ciênc. saúde coletiva. 2005; 10(2):483-491.

MELLO CR, SÁ CAM, CURI N, MELLO MJ, VIOLA RM, SILVA MA. Erosividade mensal e anual da chuva no Estado de Minas Gerais. Pesq. Agropec. Bras. 2007; 42(4):537-545.

OLIVEIRA JR. RS, REGITANO JB. Dinâmica de pesticidas no Solo. In: MELO VF, ALLEONI LRF, editors. Química e Mineralogia do Solo. Minas Gerais: SBCS. Viçosa; 2009. p. 188-241.

OLIVEIRA NETO O F DE, ARENAS AY, FOSTIER AH. Sorption of thiabendazole in subtropical Brazilian soils Environ Sci Pollut R. 2017; 24:16503-16512.

ORGANISATION FOR ECONOMIC CO-OPERATION AND DEVELOPMENT OECD (2000) Test No. 106: Adsorption-Desorption Using a BatchEquilibrium Method. Available from: https://www.oecd-ilibrary.org/environment/test-no-106-adsorption-desorption-using-abatch-equilibrium-method_9789264069602-en.

PEREIRA LA, JARDIM ICSF, FOSTIER AH, RATH S. Ocorrência, comportamento e impactos ambientais provocados pela presença de antimicrobianos veterinários em solos. Quím. Nova. 2012; 35(1):159-169.

RATH S, PEREIRA LA, DAL BOSCO SM, MANIERO MG, FOSTIER AH, GUIMARÃES JR. Fate of ivermectin in the terrestrial and aquatic environment: mobility, degradation, and toxicity towards Daphnia similis. Environ Sci Pollut R. 2016; 23(6):5654-5666.

RIBANI M, BOTTOLI CBG, COLLINS CH, JARDIM ICSF, MELO L FC. Validação em métodos cromatográficos e eletroforéticos. Quím. Nova. 2004; 27(5):771-780.

SARMAH AK, MEYER MT, BOXALL ABA. A global perspective on the use, sales, exposure pathways, occurrence, fate and effects of veterinary antibiotics (VAs) in the environment. Chemosphere. 2006; 65(5):725-759.

SINDAN (Sindicato Nacional da Industria de Produtos para a Saúde Animal) (2018) [internet] Data on the Brazilian market for veterinary products. Available from: http://www.sindan.org.br/sd/base.aspx?controle=8.

SINGH S, SINGH N, KUMAR V, DATTA S, WANI AB, SINGH D et al. Toxicity, monitoring and biodegradation of the fungicide carbendazim. Environ Chem Lett. 2016:14:317-329.

SOARES MR, ALLEONI LRF. Contribution of soil organic carbon to the ion exchange capacity of the tropical soils. J. Sustain Agr. 2008; 32(3):439-462.

VIEIRA AP, RATH S, FOSTIER AH. Sorption of sulfachloropyridazine in Brazilian soils. J. Braz. Chem. Soc. 2017; 28(1):158-167.

ZAHRA T, AHMAD KS, SHAHEEN I, AZHAR S, JAFFRI SB. Determining the adsorption and desorption behavior of thiabendazole fungicide for five different agricultural soils. Soil Environ. 2017:36(1): 13-19. 